\title{
PENERAPAN TEKNOLOGI PEMBUATAN TRIKOKOMPOS DI DESA SUNGAI BOKOR KALIMANTAN SELATAN
}

\author{
Mariana dan Ismed Setya Budi \\ Prodi Proteksi Tanaman, Fakultas Pertanian, Universitas Lambung Mangkurat \\ Email : mariana@ulm.ac.id
}

\begin{abstract}
ABSTRAK
Karet merupakan sumber penghasilan utama bagi pekebun di Desa Sungai Bokor. Selain berprofesi sebagai pekebun karet, juga sebagai peternak kambing ettawa. Namun Kotoran kambing menjadi polusi dan tidak dimanfaatkan. Hal ini sangat potensial untuk dimanfaatkan sebagai media aplikatif dari Trichoderma menjadi produk Trichokompos. Tujuan kegiatan pengabdian ini adalah melatih dan mendampingi pekebun dan peternak untuk teknologi produksi Trikokompos. Kegiatan ini diawali dengan metode penyuluhan yaitu tentang penyakit karet, kompos dan Trikokompos. Kemudian dilanjutkan dengan pelatihan dan pendampingan yang telah disepakati antara pelaksana dan mitra berlangsung yang dalam 2 (dua) tahap. Tahap I adalah pelatihan penyediaan kultur murni Trichoderma indigenous dan pembuatan starternya. Tahap ini dilatihkan dan didampingi oleh Tim pelaksana. Tahap II dilaksanakan oleh Mitra yang dilatihkan dan didampingi oleh Tim pelaksana, yaitu produksi massal Trikoberas, kompos dan Trikokompos. Hasil dari kegiatan ini adalah pekebun dan peternak memahami tentang penyakit karet dan kompos serta Trikokompos. .Mitra telah berhasil memproduksi Trikokompos sebanyak $750 \mathrm{~kg}$. Setelah kegiatan Intensitas penyakit Jamur Akar Putih di kebun karet di desa Sungai Bokor sudah menurun sekitar 50\%.
\end{abstract}

Kata kunci : Penerapan teknologi sederhana, Trikokompos, Karet.

\section{PENDAHULUAN}

Karet merupakan sumber penghasilan utama bagi pekebun di Desa Sungai Bokor. Pada perkebunan rakyat pengelolaan tanaman tidak seperti layaknya Perusahaan Besar yang mempunyai kemampuan lebih untuk hal tersebut. Di Kalimantan Selatan perkebunan karet didominasi oleh kebun rakyat. Total luas area perkebunan karet adalah seluas 262.295 Ha , meliputi : Perkebunan Rakyat : 235.826 Ha $(90,08 \%)$, Perkebunan
Besar Negara : 13.025 Ha (5,05\%), dan Perkebunan Besar Swasta : $13.444 \mathrm{Ha}$ $(4,87 \%)$. Produktivitas karet di Kalimantan selatan $\quad 1.047 \quad \mathrm{~kg}$ sheet/tahun berada di bawah produktivitas nasional $1.500 \quad \mathrm{~kg}$ sheet/tahun atau hanya $63,85 \%$ dari potensi produktivitas karet, hal ini karena kondisi tanaman yang sebagian sudah tua dan rusak (30\%), dan terserang Jamur Akar Putih (JAP) pada tanaman karet produktif. Di Kabupaten Banjar pada perkebunan rakyat 
produktivitas cukup rendah yaitu hanya $858 \mathrm{~kg} / \mathrm{ha}$ dengan jumlah petani 16.983 orang dan luas lahan 24.770 Ha (Dinas Pekebunan Prov. Kal Sel). Kacamatan Mataraman merupakan salah satu daerah produsen karet. Di daerah ini terdapat pabrik pengolahan karet yaitu PTPN XIII Danau .Salak dengan kapasitas pabrik 40.000 ton/th dan kapasitas terpakai 12.000 ton/th, dan bentuk produksi berupa Ribbed Smoked Sheet (RSS). Di sekitar perusahan umumnya masyarakat menanam karet sebagai perkebunan rakyat d esa Sungai Bokor. Luas desa $30,40 \mathrm{~km}$. Selain berprofesi sebagai pekebun karet, juga sebagai peternak kambing ettawa dengan populasi kambing 137 ekor.

Serangan patogen $R$. lignosus (jamur akar putih) menyebabkan akar menjadi busuk dan umumnya ditumbuhi rizomorf cendawan. Gejala tampak pada daun; daun-daun yang semula tampak hijau segar berubah menjadi layu, berwarna kusam, dan akhirnya kering. Tanaman yang terserang parah akan tumbang dan mati menyisakan tunggul tunggul sumber infeksi. Beberapa cara pengendalian penyakit jamur akar putih telah dilakukan, diantaranya dengan menghilangkan tunggul-tunggul atau organ tanaman berkayu secara tuntas sebagai sumber infeksi, menanam tanaman penutup tanah jenis leguminosa, pelumasan dan penyiraman fungisida, serta pengendalian dengan menggunakan agens hayati seperti Trichoderma spp. yang bersifat antagonis terhadap pathogen (Pawirosoemardjo, 2004).

Solusi pengendalian yang ekonomis dan ramah lingkungan adalah dengan pengendalian hayati. Penggunaan produk biopestisida ini akan lebih efektif apabila diaplikasikan pada media aplikatif yang menunjang nutrisi dan kondisi lingkungan yang baik bagi mikroba antagonis. Kompos dan gulma air terbukti dapat meningkatkan kemampuan Trichoderma (Budi dan Mariana, 2015)..Biopestisida apabila sudah diaplikasikan di alam akan berkembang dengan baik apabila kondisi lingkungan biotik dan abiotiknya mendukung. Berbagai hasil penelitian menunjukkan bahwa Trichoderma merupakan jamur antagonis yang mampu mengendalikan berbagai penyakit tanaman, baik pada tanaman pertanian maupun perkebunan. Selain itu, jamur ini juga berfungsi sebagai decomposer karena kemampuannya menghasil enzim 
degredasi. (Harman Et al., 2004, Harman, 2006 ; Joshi et al. 2010 ; Chen dan Nelson, 2012).

Hasil studi karakteristik pada awal kegiatan menunjukkan bahwa pekebun mempunyai keterbatasan dalam penguasaan teknologi khususnya teknologi pengendalian jamur akar putih. Sampai sat ini kondisi penyakit yang sudah cukup parah tersebut, belum dikendalikan secara optimal. Di sisi lain, penyuluh setempat menyatakan bahwa perkembangan teknologi yang cepat menyebabkan pekebun ketinggalan. Agar potensi pekebun dapat berkembang maupun memperkuat potensi atau daya yang dimiliki pekebun di kawasan perkebunan rakyat, maka dilakukan introduksi teknologi yang dibutuhkan pekebun.

Di Desa Sungai Bokor, selain terdapat perkebunan karet, akhir akhir ini masyarakat sudah mulai beternak kambing Ettawa dengan produk berupa daging kambing dan susu kambing. Susu kambing sekarang sudah mulai dikembangkan untuk menjadi produk unggulan desa. Namun sampai sekarang kotoran kambing menjadi polusi dan tidak dimanfaatkan. Kotoran kambing ini akan dimanfaatkan sebagai media aplikatif dari Trichoderma sehingga menjadi produk biopestisida alami berupa Trichokompos

Target yang ingin dicapai pada kegiatan ini adalah melatih dan mendampingi pekebun untuk memproduksi Trikokompos dan Trikoberas dan Menurunkan intensitas penyakit jamur akar putih pada tanaman karet di desa Mitra.

\section{METODE PELAKSANAAN}

Kegiatan ini diawali dengan penyuluhan tentang hama dan penyakit karet, juga dijelaskan tentang kompos dan Trikokompos. Pada tahap awal pekebun/peternak yang dilatih diseleksi berdasarkan tingkat pendidikan karena teknologi ini memerlukan ketrampilan dan pengetahuan yang telah diperoleh di tingkat Sekolah Menengah Atas. Empat petani dan peternak yang terpilih pada awal pertemuan seluruh anggota kelompok, dilatih dan didampingi untuk mengaplikasikan teknologi pengkayaan kompos kotoran kambing untuk produksi Trikoberas, pengomposan dan Trikokompos., Pada implementasi konsep pemberdayaan masyarakat menggunakan pendekatan kelompok. Untuk itu, dilakukan rekayasa sosial untuk pemberdayaan pekebun, melalui pelatihan dan 
pendampingan yang intinya mengarah pada penciptaan suasana iklim yang memungkinkan potensi peternak dan pekebun berkembang.

$$
\text { Kegiatan ini yang telah }
$$
disepakati antara pelaksana dan mitra berlangsung yang dalam 2 (dua) tahap. Tahap I adalah penyediaan kultur murni Trichoderma dan pembuatan starternya. Tahap ini dilaksanakan oleh Tim pelaksana. Tahap II dilaksanakan oleh Mitra yang dilatihkan dan didampingi oleh Tim pelaksana, yaitu produksi massal Trikoberas, kompos dan Trikokompos. Secara rinci kegiatan tersebut meliputi: a. Pelaksana membuat kultur murni Trichoderma yang diisolasi dari daerah Mitra, kemudian membuat kultur padat dalam media beras sehingga menjadi Starter; b. Mitra dilatih dan didampingi memproduksi massal Trikoberas dari starter; c. Mitra dilatih membuat mengolah kotoran kambing menggunakan Trichoderma menjadi kompos kotoran kambing; d. Mitra dilatih dan didampingi untuk memproduksi massal Trikokompos yaitu dari starter yang diaplikasikan ke kompos kotoran kambing; e. Dilakukan pendampingan, yang fungsinya sebagai fasilitator dalam membantu mencari pemecahan masalah yang tidak dapat dilakukan oleh Pekebun; f. Pekebun dilatih dan didampingi untuk metode aplikasi produk ke perkebunan karetnya.

Evaluasi dilakukan diakhir kegiatan yaitu kemampuan peserta dalam memproduksi kompos dan Trichokompos baik kualitas maupun kuantitas. Kemampuan peserta dalam mengaplikasikan produk dievaluasi diawal dan diakhir kegiatan dengan menghitung intensitas penyakit jamur akar putih. Perhitungan intensitas penyakit berdasarkan Omorusi et al (2014).

\section{HASIL DAN PEMBAHASAN}

Kegiatan diawali dengan penyuluhan yang dilaksanakan di rumah salah satu ketua kelompok tani yang menjelaskaan penyakit tanaman tanaman. Materi penyuluhan juga menjelaskan tentang cara pembuatan kompos organik berbahan dasar kotoran kambing dengan dekomposer Trichoderma sp. Pengenalan pengendali biologis terhadap jamur penyebab penyakit akar putih pada tanaman karet juga dijelaskan. Kegiatan penyuluhan yang dihadiri oleh masing-masing ketua dan semua anggota kelompok tani, kelompok wanita tani (KWT) 
mendapatkan respon yang baik. Semua petani terlibat dalam diskusi dan tanyajawab terkait materi penyuluhan serta menyatakan siap untuk melaksanakan tahapan kegiatan pengabdian selanjutnya (Gambar 1.) Dalam diskusi yang dilakukan ditetapkan pula jadwal dan tempat pelaksanaan kegiatan selanjutnya yaitu pelatihan pembuatan Triko beras, dan kemudian pelatihan pembuatan Trikokompos tentang persiapanpersiapan untuk melaksanakan teknologi pengendalian jamur akar putih pada tanaman karet secara alami.
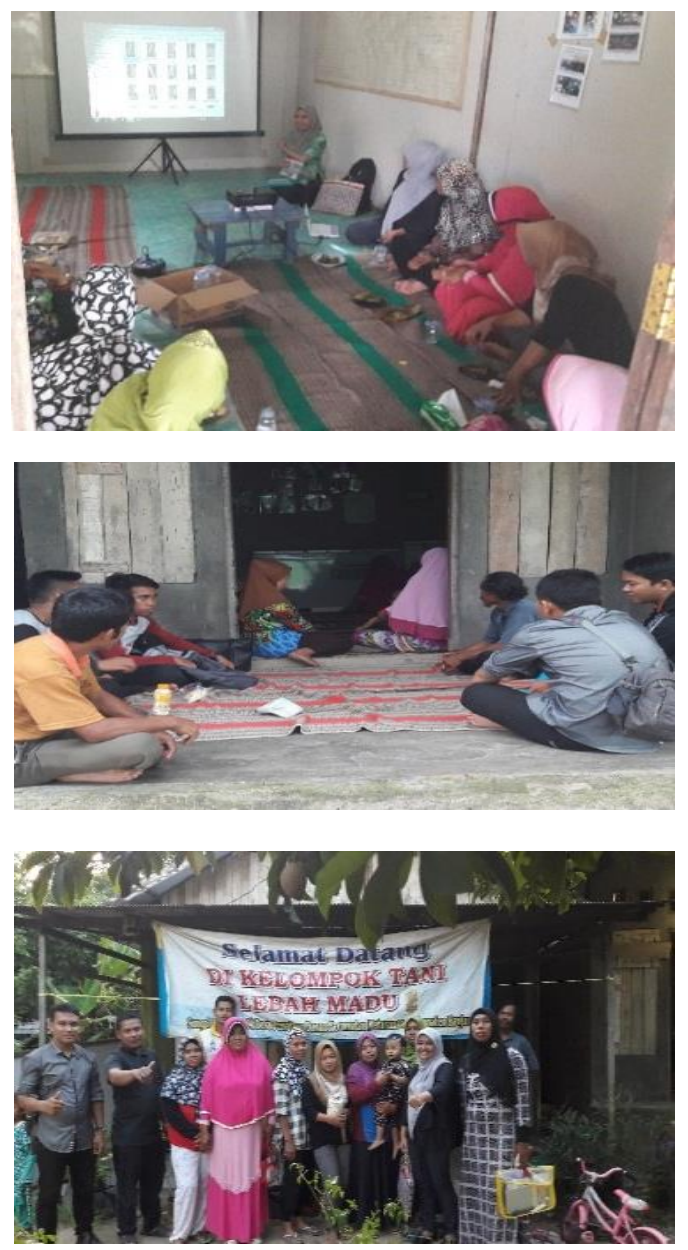

Gambar 1. Suasana pada saat penyuluhan penyakit karet dan biopestisidanya

Hasil pelatihan menunjukkan mitra sudah berhasil menguasai teknik sederhana pengambilan sampel Trichoderma spesifik lokasi menggunakan potongan bambu dan nasi basi (Gambar 2a). Isolat Trichoderma hasil isolasi dilaboratorium pengendalian hayati ULM digunakan sebagai starter membuat Triko beras.
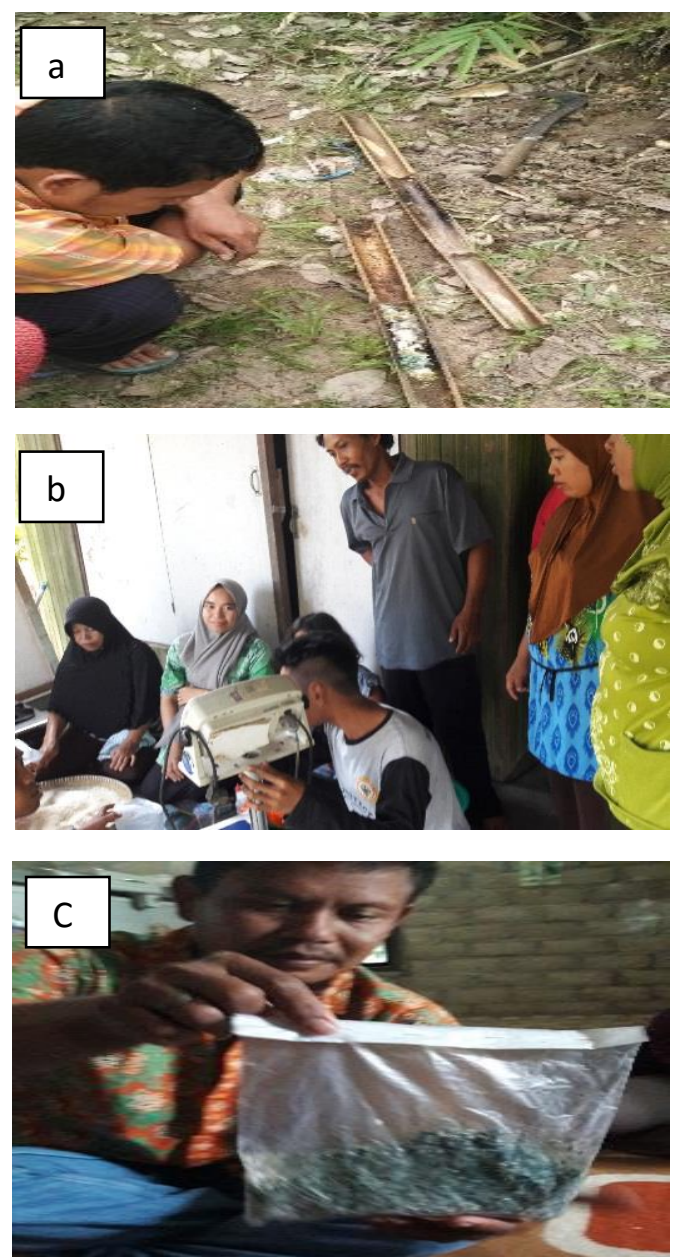

Gambar 2. Kegiatan pembuatan Trikoberas, a. pengambilan sampel 
Trichoderma spesifik lokasi; b. dekomposer jamur Trichoderma pembuatan Trikoberas; c. Hasil (Gambar 3a dan 3b). Trikokompos hasil Trikoberas produksi Mitra

Kegiatan ini dilatihkan oleh Tim pelaksana di sekretariat kelompok tani lebah madu desa Sungai Bokor. Teknologi pembuatan biopestisida ini sangat menarik minat peserta karena teknik perbanyakan cendawan Trichoderma sp. secara langsung baru pertama kali mereka lihat sehingga saat kegiatan pembuatan tersebut banyak pertanyaan yang diajukan oleh mitra yang menandakan keinginan tahu mereka cukup tinggi, bahkan ibu-ibu dari kelompok wanita tani ikut serta dalam kegiatan tersebut (Gambar 2b). Dalam waktu satu minggu media beras hasil pelatihan sudah penuh ditumbuhi oleh jamur Trichoderma. Keadaan ini semakin menguatkan dan memperbesar minat mitra akan kegiatan ini. (Gambar 2c).

Pelatihan pembuatan Trikokompos diawali dengan ketua dan anggota kedua kelompok tani menyiapkan kotoran kambing yang akan digunakan sebagai bahan dasar pembuatan Trikokompos. Selanjutnya kelompok tani yang didampingi oleh tim pengabdian, melakukan pembuatan kompos dengan menggunakan pelatihan berhasil didapat setelah 4 minggu diinkubasi(Gambar 3c dan 3d).
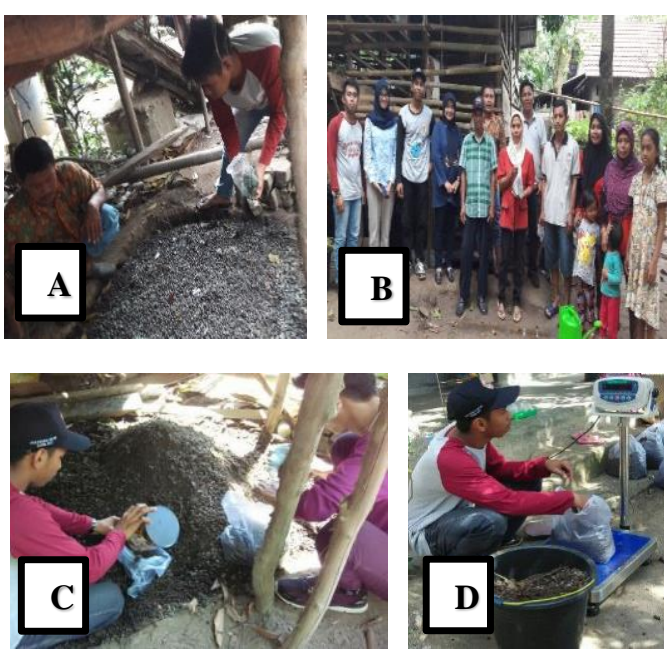

Gambar 3A dan 3B : Pelatihan pembuatan Trikokompos.

Gambar 3C dan 3D : Trikokompos hasil pelatihan

Trikokompos hasil pelatihan, diaplikasikan dengan demplot pada tanaman karet di kebun karet milik peserta. Berdasarkan perhitungan menggunakan rumus efektivitas Henderson dan Tilton (Ditlinbun, 2014) yaitu :

$$
\mathrm{EI}=\left(1-\frac{\mathrm{Ta}}{\mathrm{Ca}} \times \frac{\mathrm{Cb}}{\mathrm{Tb}}\right) \times 100 \%
$$

$\mathrm{EI}=$ Keefektifan APH yang diuji (\%)

$\mathrm{Ca}=$ Kerusakan pada petak control setelah aplikasi APH

$\mathrm{Cb}=$ Kerusakan pada petak control sebelum aplikasi APH 
$\mathrm{Ta}=$ Kerusakan pada petak perlakuan setelah aplikasi APH

$\mathrm{Tb}=$ Kerusakan pada petak perlakuan sebelum aplikasi APH
Hasil perhitungan efektivitas tersebut, Trikokompos yang digunakan sudah mampu menurunkan intensitas penyakit JAP dengan efektifitas lebih dari 50\% (Tabel 1). Hal ini sudah melampaui target yang ditetapkan.

Tabel 1. Intensitas penyakit JAP setelah 4 minggu aplikasi beberapa taraf dosis Trikokompos

\begin{tabular}{clccc}
\hline No. & Perlakuan & & $\begin{array}{c}\text { Intensitas Penyakit } \\
\text { JAP }(\%)\end{array}$ & \% Efektivitas \\
& & & 50.00 & 52.78431 \\
$\mathbf{1}$ & Trichoderma & 53.13 & 75.0 & 0 \\
\hline $\mathbf{2}$ & Kontrol & 37.6 & 21.88 & 60.98148 \\
\hline $\mathbf{3}$ & Trikokompos 1 kg & 28.13 & 59.38 & 33.80787 \\
\hline $\mathbf{4}$ & Trikokompos 2 kg & 45.00 & 50.00 & -0.34337 \\
$\mathbf{5}$ & Trikokompos 3 kg & 25.00 & 75.00 & 24.75 \\
\hline $\mathbf{6}$ & Trikokompos 4 kg & 50.00 & &
\end{tabular}

\section{DAFTAR PUSTAKA}

Budi, I.S dan Mariana. 2015. The Application of Endophytic Trichoderma viride PS-3.7 Using Indigenous Tidal Swamp Aquatic Weeds Media to Control Paddy Wilt Disease. Asian Journal of Applied Sciences 03 (1) : 191-195

Chen, M, H. dan Nelson, E, B. 2012. Microbiological-induced carbon competition in the stermosphere leads to pathogen and disease suppression in a municipal biosolids compost. Taiwan Agricultural Research Institute. Zhongzheng, Taiwan.

Cook, R.J. and Baker, K.F. 1983. The Nature and Practice of Biological Control of Plant Pathogens. The American Phytopathol. Society, St. Paul MN
Dinas Perkebunan Provinsi Kalimantan Selatan. 2010. Laporan Tahunan Dinas Perkebunan Provinsi Kalimantan Selatan.

Ditlinbun (Direktorat Perlindungan Perkebunan). 2014. Pedoman Uji Mutu Dan Uji Efikasi Lapangan Agens Pengendali Hayati (APH). Direktorat Perlindungan Perkebunan. Kemeterian Pertanian.

Joshi, BB. Bhatt, R.P. dan Bahukhandi, D. 2010. Antagonistic and Plant Growth activity Trichoderma isolates of Western Himalayas. Journal of Environmental Biology. India.

Mariana. Budi, I.S. Aphrodhyanti, L., Yusriadi, M. 2014. Efikasi Trichoderma Dalam Mengendalikan Penyakit Jamur Akar Putih pada Tanaman Karet. Laporan Penelitian 
Omorusi, V.I., Eguavoen, O.I., Ogbebor, N.O., Bosah, B.O., Orumwense, K., Ijie, K. 2014. Control of White Root Rot Disease in Rubber Plantations in Nigeria. International Journal of Microbiology and Immunology Research 3(4) : 046-051

Pawirosoemardjo S. 2004. Manajemen pengendalian penyakit penting dalam upaya mengemankan target produksi karet nasional tahun 2020. Proc.Pertemuan teknis.Pusat Penelitian Karet Balai Penelitian sembawa. Sembawa.
Harman, G.E., Howel, C.R., Viterbo, A., Chet, I., and Lorito, M. 2004. Trichoderma species opportunistic, avirulent plant symbionts.Natural Reviews, Microbilogy. .2 : 43-56.

Howell C. R. ,L. E. Hanson , R. D. Stipanovic, and L. S. Puckhaber. 2000. Induction of Terpenoid Synthesis in Cotton Roots and Control of Rhizoctonia solani by Seed Treatment with Trichoderma virens. Phytopathology 90 (3) :248-252. 